\title{
A conversion layer based on trivalent chromium and cobalt for the corrosion protection of electrogalvanized steel
}

\author{
A.R. Di Sarli ${ }^{\text {a }}$, J.D. Culcasi ${ }^{\text {b }}$, C.R. Tomachuk ${ }^{\mathrm{c}}$, C.I. Elsner ${ }^{\mathrm{a}, \mathrm{b}}$, J.M. Ferreira-Jr ${ }^{\mathrm{d}}$, I. Costa ${ }^{\mathrm{d}, *}$ \\ a CIDEPINT: Research and Development Centre in Paint Technology (CICPBA-CONICET LA PLATA), Av. 52 s/n entre 121 y 122, CP. B1900AYB La Plata, Argentina \\ ${ }^{b}$ Engineering School, National University of La Plata, Av. 1 Esq. 47, CP. B1900TAG La Plata, Argentina \\ c Engineering School of Lorena of the University of São Paulo (EEL-USP), Estrada do Campinho s/n, CEP 12602-810 Lorena, SP, Brazil \\ d Energy and Nuclear Research Institute, IPEN/CNEN-SP, CCTM, Av. Prof. Lineu Prestes, 2242, CEP 05508-000 São Paulo, SP, Brazil
}

\section{A R T I C L E I N F O}

\section{Article history:}

Received 27 April 2014

Accepted in revised form 25 August 2014

Available online 1 September 2014

\section{Keywords:}

Corrosion

Electrochemical properties

Coatings

SEM

EDXS

XPS

\begin{abstract}
A B S T R A C T
The corrosion resistance of pure zinc coatings can be improved through the application of suitable chemical passivation treatments. Hexavalent chromium $\left(\mathrm{Cr}^{6+}\right)$ compounds have widely been used to formulate conversion layers providing better anticorrosive protection as well as anchorage properties to painting systems. However, taking into account that they are produced using hazardous chemical compounds, the development of alternative and "green" technologies with equivalent protective performance is a paramount purpose of many R\&D laboratories working around the world. In the present paper, the corrosion behavior of industrially electrogalvanized steel subjected to a $\mathrm{Cr}^{3+}+\mathrm{Co}^{2+}$-based passivation treatment was studied. The experimental work involved electrochemical impedance spectroscopy (EIS) measurements and polarization curves in a $0.1 \mathrm{~mol} / \mathrm{L} \mathrm{Na}_{2} \mathrm{SO}_{4}$ solution, surface microstructural and morphological characterization by electronic microscopy as well as chemical analysis by EDXS and XPS. The most commonly observed failures on the $\mathrm{Cr}^{6+}$ treated samples were attributed to microstructural features of the substrate that were not adequately healed by the $\mathrm{Cr}^{6+}$ passivation treatment.
\end{abstract}

\section{Introduction}

Electroplated zinc coatings are largely employed as active galvanic protection for steel substrates. However, as the zinc is an electrochemically high reactive metal, its corrosion rate might be very high, even under outdoor exposure conditions [1]. For this reason, a posttreatment is necessary to increase the lifetime of zinc coatings. In industrial practice, this treatment consists of immersion in a chemical bath that forms a conversion coating on the electroplated zinc layer. Such a layer behaves as a dielectric passive coating with high corrosion resistance that also offers good adherence to paints. The main problem of the traditionally used post-treatments is the presence of $\mathrm{Cr}^{6+}$ salts, considered carcinogenic substances increasingly forbidden by European standards $[2,3]$.

In this respect, chemicals such as molybdates [4-6], tungstates [7-9], permanganates [10-12], and vanadates [13-15] were among the first alternatives tested as potential replacements for hexavalent chromium

\footnotetext{
* Corresponding author.

E-mail addresses: ardisarli@cidepint.gov.ar (A.R. Di Sarli), jculcasi@ing.unlp.edu.ar (J.D. Culcasi), celiatomachuk@usp.br (C.R. Tomachuk), cielsner@ing.unlp.edu.ar (C.I. Elsner), icosta@ipen.br (I. Costa).
}

conversion coatings. As well, other alternative coatings based on zirconium and titanium salts [16-18], cobalt salts [19,20], organic polymers [21-23], silane [24-31], and cations such as $\mathrm{Ce}^{3+}$ [32-38], $\mathrm{Mg}^{2+}$ [39], and $\mathrm{Ca}^{2+}[40-42]$, or other organic anions such as carboxylates [43-45], are considered as alternative potential non-toxic safe inhibitors.

Surface treatments based on $\mathrm{Cr}^{3+}$ are among the alternative treatments to $\mathrm{Cr}^{6+}$ conversion coatings, with the advantage that $\mathrm{Cr}^{3+}$ reduces health hazards from airborne chromium. Furthermore, the waste treatment and final disposal costs are reduced as the process needs low metal concentration, and does not use $\mathrm{Cr}^{6+}$ or additives with strong oxidants [33]. Besides, it forms a layer that acts as a barrier.

Despite some similarities between the $\mathrm{Cr}^{6+}$ - and $\mathrm{Cr}^{3+}$-based treatments, the mechanisms by which these two technologies convert a coated zinc surface are radically different. Chromium has six oxidation levels; however, only trivalent chromium oxide is extremely stable.

It is important to emphasize that trivalent blue chromates usually have a layer thickness of nearly $80 \mathrm{~nm}$, consequently it does not provide as good corrosion protection as the thicker yellow hexavalent chromate $(300 \mathrm{~nm})$ [46]. In order to be a potential replacement for $\mathrm{Cr}^{6+}$ layers, trivalent chromate ones should have a thickness greater than $100 \mathrm{~nm}$ and $\mathrm{a} \mathrm{Cr}^{3+}$ content superior to $30 \mu \mathrm{g} / \mathrm{cm}^{2}$. Therefore, a lot of investigations have been undertaken to improve its properties. 
The formation of the conversion layers from $\mathrm{Cr}^{3+}$ solutions occurs in two steps.

First step: zinc dissolves at the surface due to the acidic attack:

$$
\mathrm{Zn}+2 \mathrm{H}^{+} \rightarrow \mathrm{Zn}^{2+}+\mathrm{H}_{2} \uparrow .
$$

Second step: zinc precipitates at the zinc surface with $\mathrm{Cr}^{3+}$ as zinc chromium oxides:

$$
\mathrm{Zn}^{2+}+\mathrm{xCr}^{3+}+\mathrm{yH}_{2} \mathrm{O} \leftrightarrow \mathrm{ZnCr}_{\mathrm{x}} \mathrm{O}_{\mathrm{y}}+2 \mathrm{yH} .
$$

A kinetic model comprising differential equations for the concentration development of $\mathrm{Zn}^{2+}, \mathrm{H}^{+}$, and $\mathrm{Cr}^{3+}$ and for the thickness growth of the $\mathrm{ZnCr}_{\mathrm{x}} \mathrm{O}_{\mathrm{y}}$ layer was proposed. The mathematical expressions for the kinetic reaction take into account that the rate of the first step increasingly slows down due to the growing passive layer [46].

In industrial practice, the corrosion resistance of coated materials is usually evaluated using accelerated tests such as salt spray [47], Kesternich test [48] or saturated humidity chamber [49]. However, in the last decades, EIS has also been proven to be a useful tool to evaluate the corrosion resistance of coated metals [50-53].

The aim of the present work is to evaluate the corrosion resistance properties of an environmentally friendly conversion treatment based on $\mathrm{Cr}^{3+}+\mathrm{Co}^{2+}$ ions. The effect of $\mathrm{Co}^{2+}$ ions in the passivation treatment of eletrogalvanized steels has not been investigated previously. In order to evaluate the corrosion resistance of the passive layer formed by the proposed treatment, electrochemical methods, specifically, electrochemical impedance spectroscopy and polarization methods were used. $\mathrm{A} \mathrm{Cr}^{6+}$ conversion treatment was also carried out for comparison reasons and the results were compared.

\section{Materials and methods}

\subsection{Preparation of electrogalvanized and passivated samples}

AISI 1010 steel plates $(6.5 \mathrm{~cm} \times 10 \mathrm{~cm} \times 0.1 \mathrm{~cm})$ were industrially electrogalvanized using a cyanide-free alkaline bath containing $\mathrm{Zn}^{2+}$ $(12.5 \mathrm{~g} / \mathrm{L}), \mathrm{KOH}(170 \mathrm{~g} / \mathrm{L}), \mathrm{K}_{2} \mathrm{CO}_{3}(50 \mathrm{~g} / \mathrm{L})$, additive (10 mL/L), brightening agents $(1 \mathrm{~mL} / \mathrm{L})$, and conditioner $(10 \mathrm{~mL} / \mathrm{L})$. The following conditions were used: temperature $\left(22 \pm 3{ }^{\circ} \mathrm{C}\right)$ and cathodic current density of $2 \mathrm{~A} / \mathrm{dm}^{2}$ for $45 \mathrm{~min}$.

Prior to zinc coating, all the steel plates were degreased in a sodium silicate-based alkaline solution at room temperature, by applying a current density of $4 \mathrm{~A} / \mathrm{dm}^{2}$ for 3 min for improving the surface wettability. The samples were rinsed in deionized water, activated in an ammonia bifluoride $5 \%$ solution for $30 \mathrm{~s}$, and rinsed again with deionized water.

Immediately after the electrogalvanizing step, the sample surface was activated in a $0.5 \% \mathrm{HNO}_{3}$ solution $(\mathrm{pH} 1$ ) for $10 \mathrm{~s}$, and then, rinsed with deionized water. Subsequently, the surface was passivated by either of the following treatments: (i) yellowcolored $\mathrm{Cr}^{6+}$-based conversion treatment (generally called chromate conversion coating). The parameters used were $\mathrm{pH} 1.8$, room temperature, and $30 \mathrm{~s}$ in industrially immersion bath with mechanical agitation of the material to be plated. This passivation bath was composed of sodium dichromate, sodium chloride as a conductive salt and diluted $\mathrm{HCl}$ solution for $\mathrm{pH}$ adjustment. The zincelectroplated samples with this treatment were identified as $\mathrm{Cr}^{6+}$ and were used as reference; (ii) iridescent green-colored $\mathrm{Cr}^{3+}+\mathrm{Co}^{2+}$-based conversion treatment. The parameters used were $\mathrm{pH} 1.8,60^{\circ} \mathrm{C}$, and $60 \mathrm{~s}$ in industrial immersion bath with mechanical stirring. The passivation bath was prepared with chromium nitrate, iron inhibitor, cobalt nitrate, and organic acid for $\mathrm{pH}$ adjustment, without fluorine. Samples with this treatment were called $\mathrm{Cr}^{3+}$. Finally, the samples were rinsed in deionized water and dried in an oven at $80{ }^{\circ} \mathrm{C}$ for $15 \mathrm{~min}$. All samples were stored in desiccators at ambient temperature until being used for the immersion test.

\subsection{Chemical composition and thickness measurements}

The coating thickness was measured using an X-ray Fluorescence Method B, according to ASTM 568-98(2009) standard [54].

\subsection{Semi-quantitative chemical analyses and morphology}

The coating morphology was characterized by SEM studying surface using a Leo Stereoscan 440-Zeiss, prior and after the corrosion tests, while their composition was semiquantitatively analyzed by EDXS with a Si detector and $20 \mathrm{keV}$ energy. The samples for cross-section observations were fractured in liquid nitrogen and then these were immediately analyzed.

\subsection{XPS measurements}

The outermost surface layers of the coatings on $\mathrm{Cr}^{3+}+\mathrm{Co}^{2+}$-based conversion treatment were analyzed by means of X-ray photoelectron spectroscopy (XPS). XPS spectra were taken by exciting with $1350 \mathrm{eV}$ radiation ( $\mathrm{MgK} \alpha$, non-monochromatic), $13 \mathrm{kV}$ anodic voltage, and $300 \mathrm{~W}$ power, by means of a $\mathrm{K}^{-\mathrm{ALPHA}^{\mathrm{TM}}{ }^{+}}$X-ray photoelectron spectromer (XPS) system. Quantification was performed taking into account the relative sensitivities and assuming that the elements were homogeneously distributed in the analyzed volume.

The spectra were corrected for satellites caused by the nonmonochromatic nature of the incident X-ray source and also for the kinetic energy-dependent transmission of the spectrometer by multiplying each spectral intensity with its corresponding kinetic energy. Next, the background intensity was subtracted from the spectra using the Shirley method. In order to exclude any effects due to charging of the sample on the values of binding energies, all data were corrected by a linear shift such that the peak maximum of the C1s binding energy of adventitious carbon corresponded to $285 \mathrm{eV}$. Finally, a value for the relevant core-level binding energy was obtained from curve-fitting of the photoelectron emission lines using a symmetrical Gauss-Lorentz function. Three components could be fitted for chromium in the form of $\mathrm{Cr}_{2} \mathrm{O}_{3}(576 \pm 1.92 \mathrm{eV})$, and $\mathrm{CrO}_{3}(579.62 \pm 1.92 \mathrm{eV})$ in the conversion coatings [23-26].

\subsection{Electrochemical behavior}

The electrochemical cell consisted of a three-electrode arrangement where the counter electrode (CE) was a Pt sheet; the reference (RE) was a saturated calomel electrode ( $\mathrm{SCE}=+0.244 \mathrm{~V}$ vs. NHE) and the working electrode (WE), each coated steel sample with $15.9 \mathrm{~cm}^{2}$ exposed to the electrolyte.

All electrochemical measurements were performed at room temperature $\left(22 \pm 3{ }^{\circ} \mathrm{C}\right)$ in a naturally aerated $0.1 \mathrm{~mol} / \mathrm{L} \mathrm{Na}_{2} \mathrm{SO}_{4}$ solution with the electrochemical cell inside a Faraday cage to reduce external interferences. This solution was used in the corrosion evaluation tests to simulate the effects of industrial environments.

Potentiodynamic polarization curves were obtained using a Solartron 1280 electrochemical system at a sweep rate of $0.2 \mathrm{mV} / \mathrm{s}$, over the range of $\pm 0.250 \mathrm{~V}$ (SCE) from the corrosion potential ( $\mathrm{E}_{\text {corr }}$ ). Prior to the beginning of each test, the electrodes were stabilized for several minutes in the test solution.

Electrochemical impedance spectra were obtained, as a function of the immersion time in the electrolyte solution, in the potentiostatic mode at the corrosion potential $\left(\mathrm{E}_{\mathrm{corr}}\right)$, in the frequency range $10^{-2}<\mathrm{f}(\mathrm{Hz})<10^{5}$, by means of a Solartron 1255 FRA coupled to a Solartron 1286 EI and controlled by the ZPlot ${ }^{\circledR}$ program. A sinusoidal signal with $8 \mathrm{mV}$ of amplitude was applied and the data 
collection rates were 10 points/decade. The experimental spectra were fitted and interpreted based on equivalent electrical circuits using the software developed by Boukamp [55]. The potential stability was checked by measuring the corrosion potential after all electrochemical tests to confirm that the potential variation did no exceed $5 \mathrm{mV}$.

All tests were carried out in triplicates to evaluate the reproducibility and the mean results obtained are reported.

\section{Results and discussion}

\subsection{Thickness measurements}

Cross-section analyses of the chromate layers obtained from solutions with $\mathrm{Cr}^{6+}$ or $\mathrm{Cr}^{3+}+\mathrm{Co}^{2+}$ showed that their thicknesses were equivalent and approximately equal to $500 \mathrm{~nm}$ (Fig. 1b and d); however, it should be noted that for obtaining similar conversion layer a

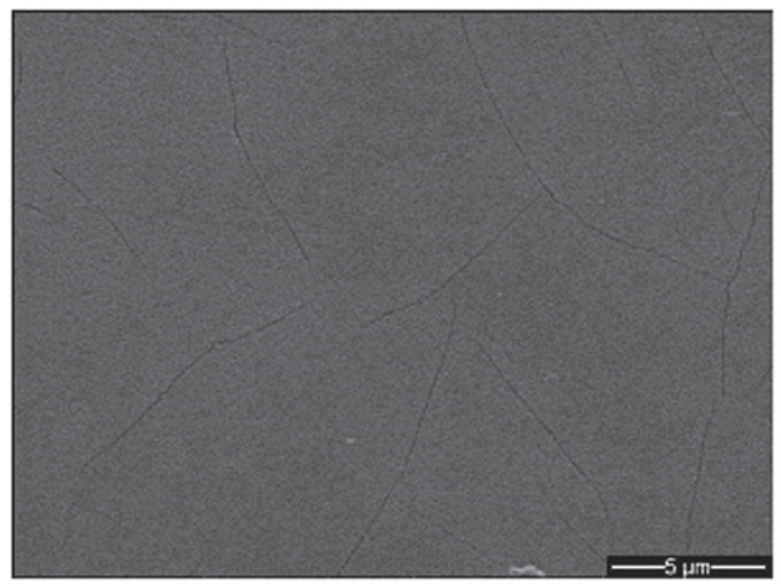

C

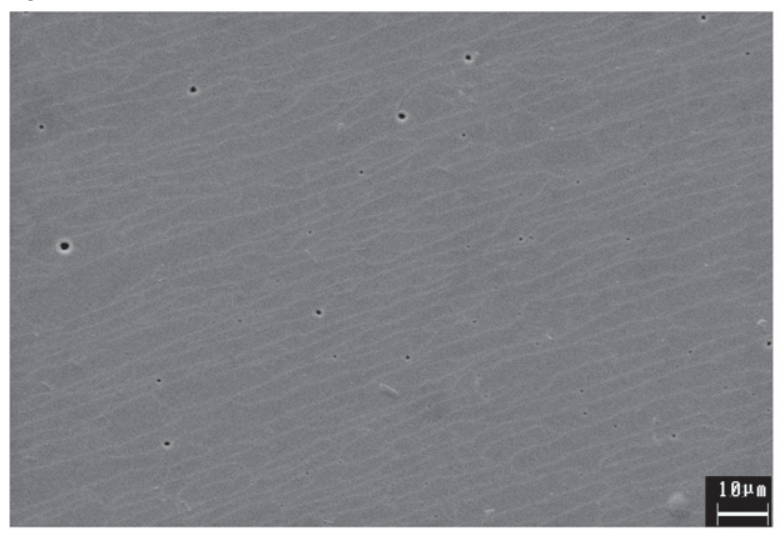

e

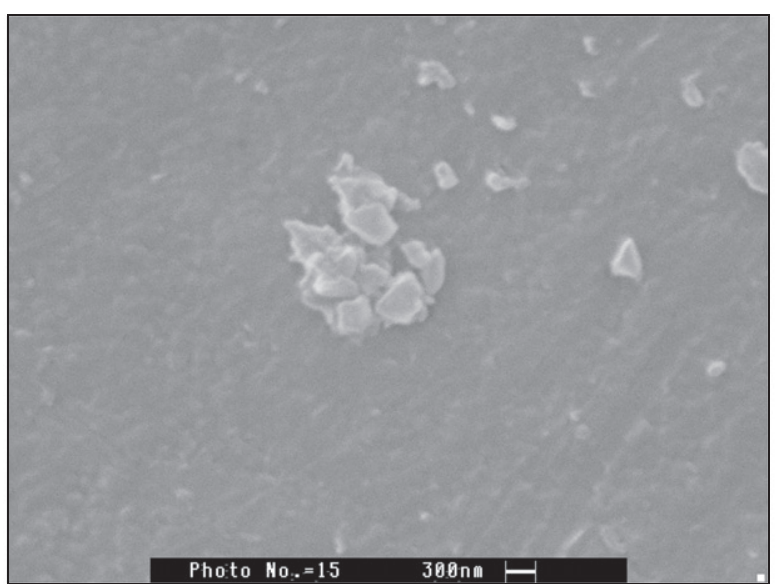

b

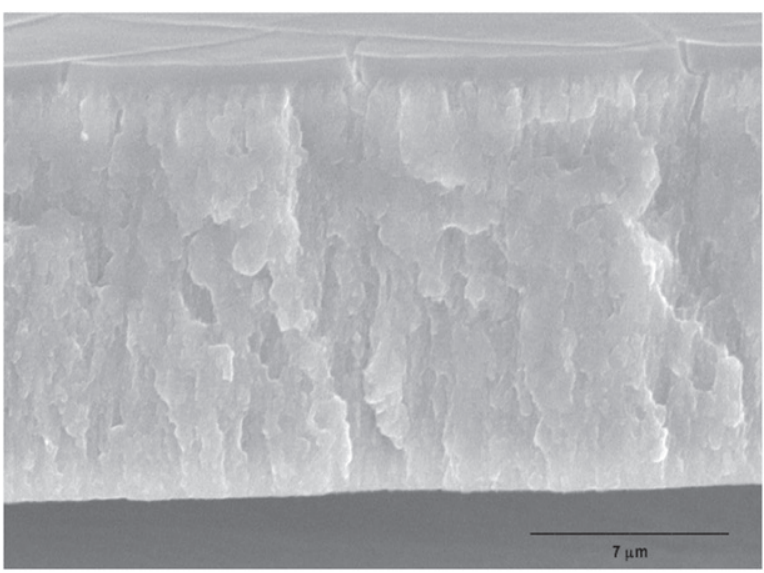

d

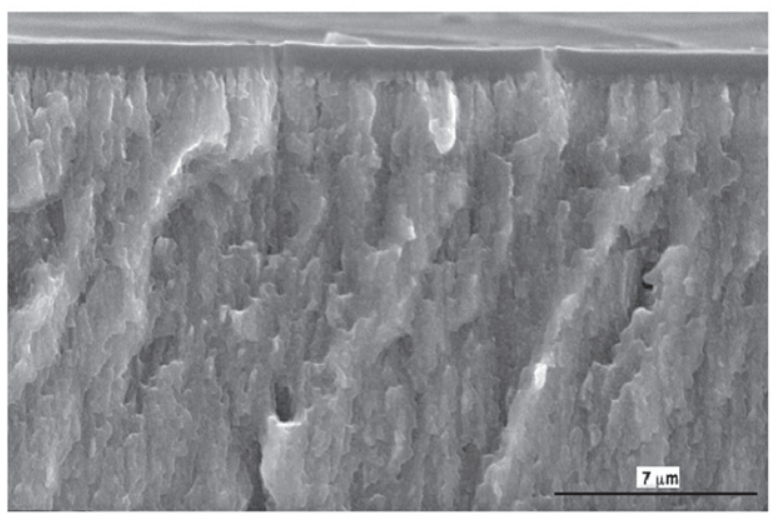

f

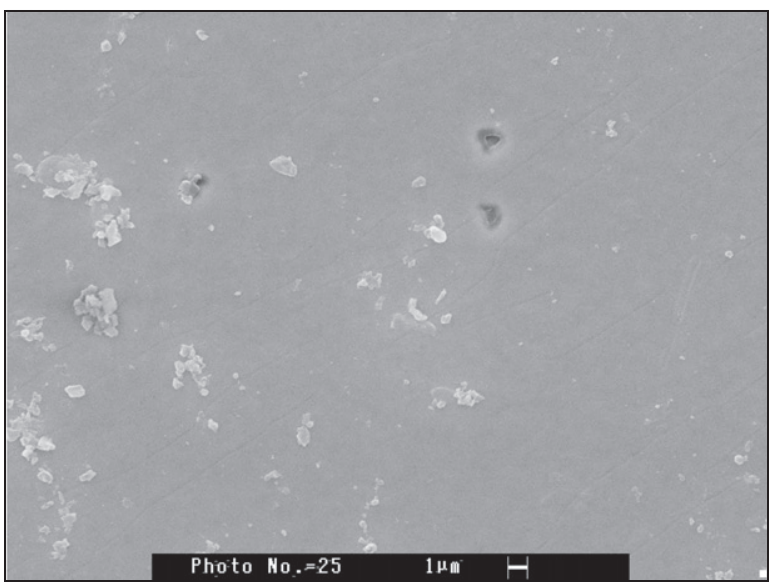

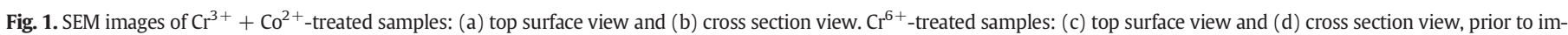
mersion. (e) $\mathrm{Cr}^{3+}+\mathrm{Co}^{2+}$ - and (f) $\mathrm{Cr}^{6+}$-treated samples after $96 \mathrm{~h}$ immersion in a $0.1 \mathrm{~mol} / \mathrm{L} \mathrm{Na}_{2} \mathrm{SO}_{4}$ solution. 
thicknesses, the immersion time in the $\mathrm{Cr}^{6+}$ bath was about half of corresponding to the $\mathrm{Cr}^{3+}$ one. On the other hand, the total protective layer $(\mathrm{Zn}+\mathrm{Cr})$ thickness, determined by the X-ray fluorescence method [54] was greater for the $\mathrm{Cr}^{6+}(14.6 \pm 2.0 \mu \mathrm{m})$ than for the $\mathrm{Cr}^{3+}+\mathrm{Co}^{2+}$ treatment $(11.4 \pm 1.5 \mu \mathrm{m})$.

3.2. Semi-quantitative chemical analyses and morphology of the passivated surfaces

The investigation of the coating morphology after the coating/drying process is very important since the presence of flaws, such as pores and/or other defects, leads to localized corrosion of the exposed zinc surface to the environment [55]. Thus, after the conversion treatment, the coating surface morphology of samples passivated in $\mathrm{a} \mathrm{Cr}^{3+}+\mathrm{Co}^{2+}$ solution, either prior or after $96 \mathrm{~h}$ of exposure to a $0.1 \mathrm{~mol} / \mathrm{L} \mathrm{Na}_{2} \mathrm{SO}_{4}$ solution was observed by SEM, Fig. 1. Cobalt ions are added to the solution in order to improve the corrosion resistance of the coating [56-58]. Thin cracks were visible. In addition, a thin layer was seen on the sample exposed to the electrolyte, likely due to the gel-like structure and low thickness of the coating layer [59-62].

SEM images of samples treated in the $\mathrm{Cr}^{6+}$ passivation bath in the as-received condition and after $96 \mathrm{~h}$ of immersion in the test electrolyte are shown in Fig. 1c and f, respectively. The surface of the samples in the as-received condition exhibited some circular holes, whose diameter was widened with immersion in the test medium. SEM observations of an $\mathrm{HNO}_{3}$ activated non-pretreated sample (not presented here) have shown the presence of wider circular features, similar to those exhibited in Fig. 1. The holes are due to defects generated in the industrial plating step that led to a surface not adequately coated by the $\mathrm{Cr}^{6+}$ conversion coating layer. Localized EDXS analyses performed inside different holes showed that the $\mathrm{Cr}$-content within them was higher than in the rest of the surface. This observation was interpreted assuming that the corrosion activity developed at the metallic surface exposed inside the holes led to the migration of $\mathrm{Cr}^{6+}$ ions from the conversion layer towards the defects to diminish the corrosive activity, i.e. the so-called self-healing effect.

Table 1 presents the results of semi-quantitative EDXS analysis of the elements at the sample surface with the two types of conversion coatings prior and after the immersion test. The results showed that the $\mathrm{Cr}$ distribution and the coating thickness were homogeneous, and the $\mathrm{Cr}$ content was higher in the $\mathrm{Cr}^{6+}$-treated samples. Co ions were not detected due to their low surface concentration. After the immersion test in the $\mathrm{Na}_{2} \mathrm{SO}_{4}$ solution, the EDXS analysis showed an enrichment of the $\mathrm{Cr}$ content at the surface, $\approx 8 \%$ for the samples with $\mathrm{Cr}^{3+}$ and $\approx 32 \%$ for those with the $\mathrm{Cr}^{6+}$ conversion layer. Likewise, by comparing the $\mathrm{Zn}$ and $\mathrm{O}$ contents in the surface layer, prior and after the immersion test, well-distinguished changes were observed. For instance, for the $\mathrm{Cr}^{3+}$-based conversion layer, $\mathrm{Zn}$ and $\mathrm{O}$ contents remained almost stable (changes $<0.5 \%$ ), whereas for the $\mathrm{Cr}^{6+}$ based conversion layer, the percentages corresponding to the $\mathrm{Zn}$ and $\mathrm{O}$ contents decreased by $\approx 11 \%$, and increased by $\approx 9 \%$, respectively.

\subsection{XPS results}

Fig. 2a-b shows the overall XPS spectra acquired from (a) a sample with $\mathrm{Cr}^{3+}+\mathrm{Co}^{2+}$ conversion coating and (b) a sample with the $\mathrm{Cr}^{6+}$ a

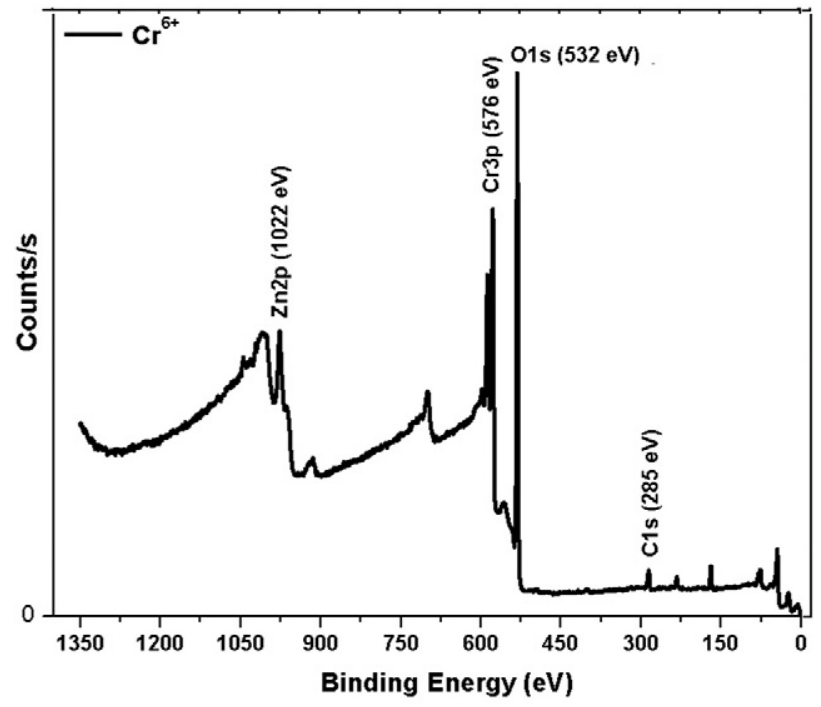

b

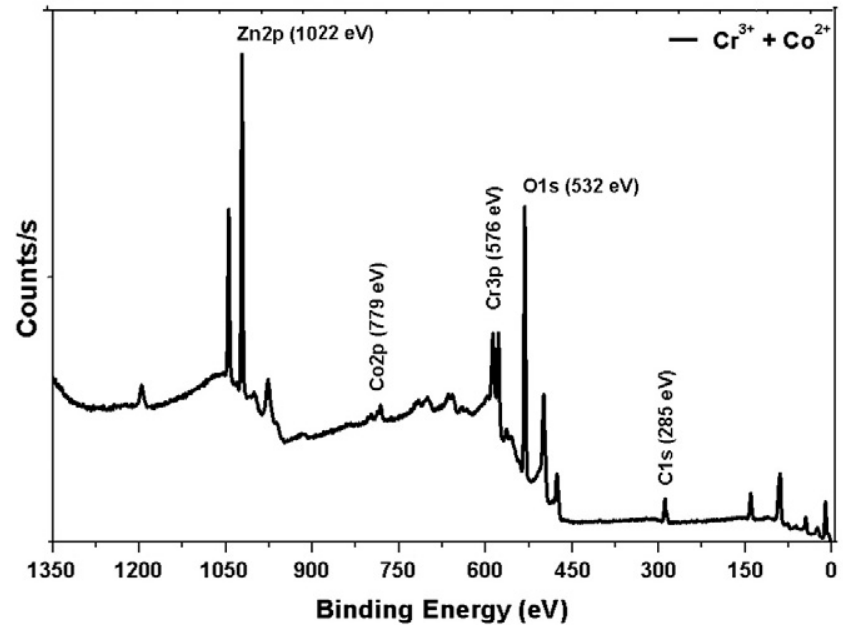

Fig. 2. XPS spectra for the (a) $\mathrm{Cr}^{6+}$ - or (b) $\mathrm{Cr}^{3+}+\mathrm{Co}^{2+}$-treated electrogalvanized steel surfaces.

conversion layer. For the $\mathrm{Cr}^{3+}+\mathrm{Co}^{2+}$ treated sample, a $\mathrm{Zn}$ signal is seen in addition to the $\mathrm{Cr}, \mathrm{O}, \mathrm{Co}$ and $\mathrm{C}$ ones. This shows that zinc oxides/hydroxides were found at the outermost surface layer of these coatings, as well as chromium oxides/hydroxides. For the $\mathrm{Cr}^{6+}$ treated sample, the spectrum of Fig. $2 \mathrm{~b}$ displays $\mathrm{Zn}, \mathrm{C}, \mathrm{Cr}$, and $\mathrm{O}$.

The chemical compositions based on the XPS survey scans were in good agreement with the expected composition (C1s, O1s, Cr3p and $\mathrm{Zn} 2 \mathrm{p})$ for $\mathrm{Cr}^{6+}$-treated samples and $\mathrm{C} 1 \mathrm{~s}, \mathrm{O} 1 \mathrm{~s}, \mathrm{Cr} 3 \mathrm{p}, \mathrm{Co} 2 \mathrm{p}$ and $\mathrm{Zn} 2 \mathrm{p}$ to $\mathrm{Cr}^{3+}+\mathrm{Co}^{2+}$-treated ones. High resolution 01s, $\mathrm{Cr} 3 \mathrm{p}$ and Co2p scans were obtained ( 50 scans with a spot size of $400 \mu \mathrm{m}$ ). Distributions of

Table 1

Semi-quantitative EDXS chemical composition at the surface samples prior and after the immersion test in $0.1 \mathrm{~mol} / \mathrm{L} \mathrm{Na} 2 \mathrm{SO}_{4}$ solution.

\begin{tabular}{|c|c|c|c|c|c|c|c|}
\hline Sample & & $\begin{array}{l}\mathrm{C} \\
\text { (at.\%) }\end{array}$ & $\begin{array}{l}\mathrm{Zn} \\
\text { (at.\%) }\end{array}$ & $\begin{array}{l}\text { O } \\
\text { (at.\%) }\end{array}$ & $\begin{array}{l}\mathrm{Cr} \\
\text { (at.\%) }\end{array}$ & $\begin{array}{l}\mathrm{Fe} \\
\text { (at.\%) }\end{array}$ & $\begin{array}{l}\text { Total } \\
\text { (at.\%) }\end{array}$ \\
\hline \multirow[t]{2}{*}{$\mathrm{Cr}^{3+}+\mathrm{Co}^{2+}$-based conversion layer } & Prior to immersion & 0.00 & 38.09 & 60.49 & 1.42 & 0.00 & 100 \\
\hline & After 96 h immersion & 0.00 & 38.96 & 59.50 & 1.54 & 0.00 & 100 \\
\hline \multirow[t]{2}{*}{$\mathrm{Cr}^{6+}$-based conversion layer } & Prior to immersion & 0.00 & 45.43 & 51.72 & 2.51 & 0.34 & 100 \\
\hline & After $96 \mathrm{~h}$ immersion & 0.00 & 40.73 & 55.87 & 3.31 & 0.09 & 100 \\
\hline
\end{tabular}


Table 2

Distributions of elements, chemical states, binding energy $(\mathrm{eV})$ and adjustment factor (FWHM).

\begin{tabular}{llrcl}
\hline Samples & Elements & (at.\%) & Binding energy $(\mathrm{eV})$ & FWHM \\
\hline $\mathrm{Cr}^{6+}$ & C1s & 6.17 & 284.9 & 1.64 \\
& Cr3p & 18.00 & 575.58 & 1.8 \\
& O1s & 74.66 & 532.00 & 1.8 \\
& Zn2p & 1.18 & 1022 & 1.35 \\
& C1s & 6.13 & 285 & 1.92 \\
& Cr3p & 16.32 & 576.01 & 1.92 \\
$\mathrm{Cr}^{3+}+\mathrm{Co}^{2+}$ & Co2p & 2.69 & 781.1 & 1.95 \\
& O1s & 56.39 & 532 & 2.31 \\
& Zn2p & 18.46 & 1022 & 3.01 \\
\hline
\end{tabular}

elements, chemical states, binding energy (eV) and adjustment factor (FWHM) were presented in Table 2.

The narrow spectrum corresponding to $\mathrm{Cr} 2 \mathrm{p}$ for the surfaces with either of the two treatments is shown in Fig. 3a-b. They were fitted with

a

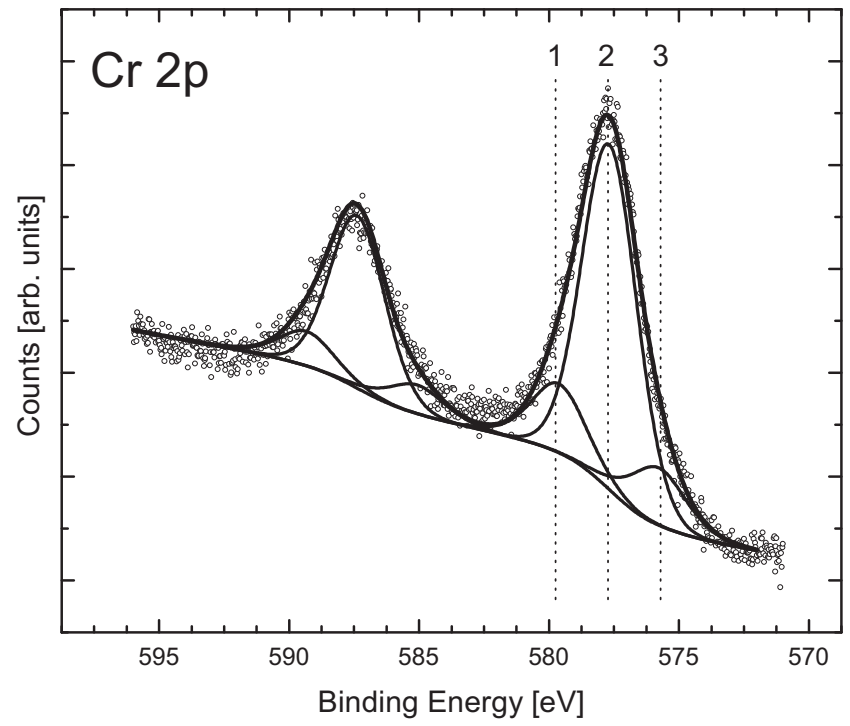

b

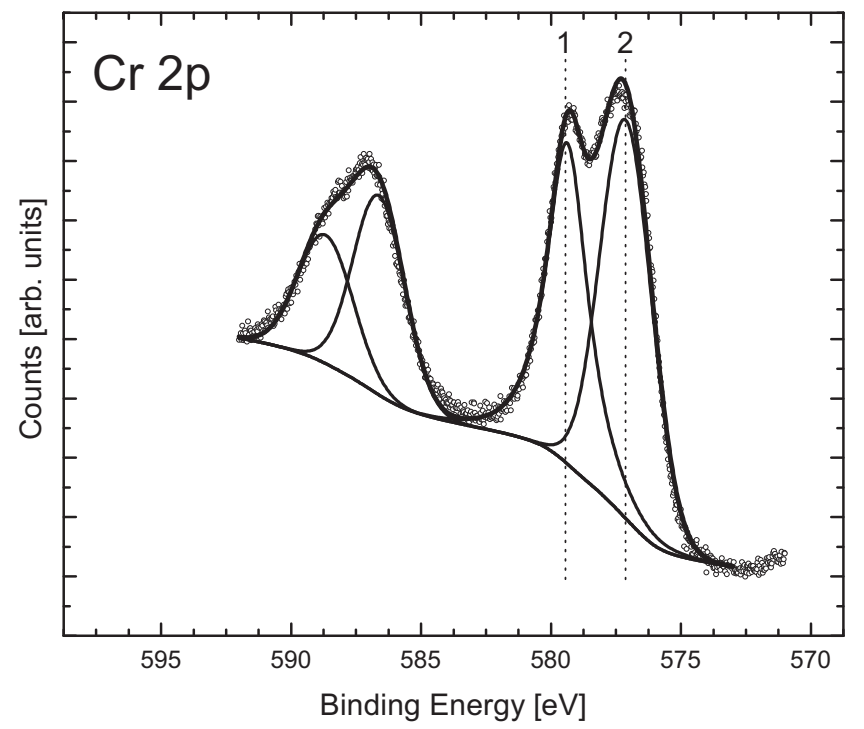

Fig. 3. $\mathrm{Cr} 2 \mathrm{p}$ XPS spectra for the (a) $\mathrm{Cr}^{3+}+\mathrm{Co}^{2+}$ - or (b) $\mathrm{Cr}^{6+}$-treated electrogalvanized steel surfaces. three component curves to estimate the quantities of $\mathrm{Cr}$ in the states $\mathrm{Cr}^{6+}, \mathrm{Cr}(\mathrm{OH})_{3}$ and $\mathrm{Cr}_{2} \mathrm{O}_{3}$, respectively. The $\mathrm{C} 1 \mathrm{~s}(\mathrm{C}-\mathrm{C} / \mathrm{C}-\mathrm{H})$ found was due to adventitious carbon or contaminants deposited on the surface during exposure to air, $\mathrm{Zn} 2 \mathrm{p}$ is due to the substrate (eletrogalvanized steel), and chromium is due to oxide/hydroxides on the surface. Cobalt was found on the $\mathrm{Cr}^{3+}+\mathrm{Co}^{2+}$-treated samples as 2.69 at.\% in the surface film.

For the $\mathrm{Cr}^{3+}+\mathrm{Co}^{2+}$-treated surface (Fig. 3a), 81.7\% (atomic percentage) of the $\mathrm{Cr}$ is found as $\mathrm{Cr}_{2} \mathrm{O}_{3}$ and the remnant $18.3 \%$ is related to $\mathrm{Cr}(\mathrm{OH})_{3}$. $\mathrm{Cr}(\mathrm{VI})$ peak was not found near $579.2 \mathrm{eV}$, indicating that no $\mathrm{Cr}(\mathrm{VI})$ was present within the outermost part of the coating on this surface [62].

For the surface with $\mathrm{Cr}^{6+}$ conversion coating (Fig. 3b), 67.7\% (atomic percentage) of chromium was found as $\mathrm{Cr}^{6+}$, specifically as $\mathrm{CrO}_{3}$ and the remnant $32.3 \%$ was found as $\mathrm{Cr}^{3+}$, precisely as $\mathrm{Cr}_{2} \mathrm{O}_{3}$. The amount of $\mathrm{Cr}^{3+}$ is found as a source of chromium that migrates to the defective regions during the self healing process related to the chromate layers [62].

\subsection{Polarization measurements}

The anodic and cathodic reactions involved in the zinc corrosion process, i.e.

dissolution of zinc : $\mathrm{Zn} \rightarrow \mathrm{Zn}^{2+}+2 \mathrm{e}^{-}$

oxygen reduction : $\mathrm{O}_{2}+2 \mathrm{H}_{2} \mathrm{O}+4 \mathrm{e}^{-} \rightarrow 4 \mathrm{OH}^{-}$

and

hydrogen reduction : $2 \mathrm{H}^{+}+2 \mathrm{e}^{-} \rightarrow \mathrm{H}_{2} \uparrow$

occurred in such a way that the former process took place at defects of the conversion layer and the latter on the surface mostly. Hence, zinc hydroxide precipitates on the surface and changes to zinc oxide gradually, forming a passive film [63], as:

$\mathrm{Zn}^{2+}+2 \mathrm{OH}^{-} \rightarrow \mathrm{Zn}(\mathrm{OH})_{2} \rightarrow \mathrm{ZnO}+\mathrm{H}_{2} \mathrm{O}$.

Fig. 4 shows typical polarization curves for $\mathrm{Cr}^{6+}$ or $\mathrm{Cr}^{3+}+\mathrm{Co}^{2+}$ passivated electrogalvanized steel samples immersed in an aerated $0.1 \mathrm{~mol} / \mathrm{L} \mathrm{Na}_{2} \mathrm{SO}_{4}$ solution. In it can be readily seen that the anodic curves did not give much information since the corresponding to both samples type were rather similar and describe an active zinc dissolution.

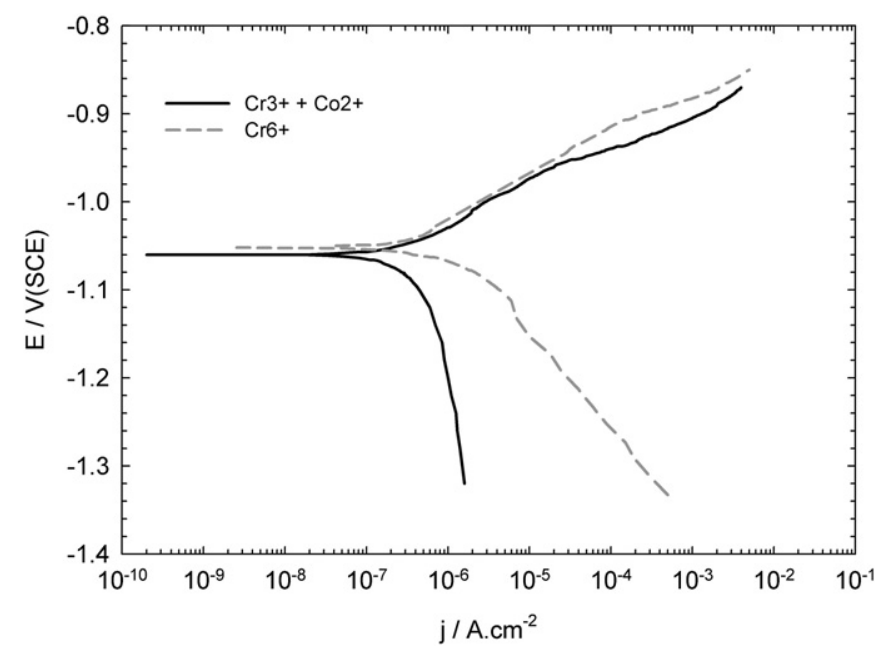

Fig. 4. Polarization curves for $\mathrm{Cr}^{3+}+\mathrm{Co}^{2+}$-treated or $\mathrm{Cr}^{6+}$-treated electrogalvanized steel samples immersed in a $0.1 \mathrm{~mol} / \mathrm{L} \mathrm{Na}_{2} \mathrm{SO}_{4}$ solution. 
This similarity was attributed to the fact that as the zinc dissolves, zinc cations may interact with water to form an insoluble zinc oxide or zinc hydroxide [64]. In $\mathrm{SO}_{4}^{2-}$ containing media, such a film is usually bulky but porous and, therefore, it could scarcely affect the zinc anodic dissolution.

The same figure also illustrates that a difference took place in the cathodic branch since the lower cathodic current density corresponding to the $\mathrm{Cr}^{3+}+\mathrm{Co}^{2+}$ passivated electrogalvanized steel samples indicated a more significant suppression of the oxygen reduction reaction.

As it can be readily observed, for the $\mathrm{Cr}^{3+}+\mathrm{Co}^{2+}$-treated sample the corrosion rate was under cathodic control (oxygen diffusion), while the $\mathrm{Cr}^{6+}$-treated sample showed not only that the cathodic current density increased but also that the rate determining step (rds) of the corrosion process was under activation control, ascribed to the hydrogen evolution reaction.

Table 3 shows the values of the electrochemical parameters obtained for the $\mathrm{Cr}^{6+}$ - and $\mathrm{Cr}^{3+}+\mathrm{Co}^{2+}$-treated samples, as well the corresponding to the steel/zinc sample added only with comparative purposes in order to determine the treatment protective efficiency. The table illustrates that whereas the corrosion potential $\left(\mathrm{E}_{\mathrm{corr}}\right)$ of the electrogalvanized steel panels untreated or treated with the different conversion layers stabilized around $-1.05 \pm 0.05 \mathrm{~V} / \mathrm{SCE}$, the corrosion current density $\left(\mathrm{j}_{\text {corr }}\right.$ ) values calculated by extrapolation of the Tafel slopes (Fig. 4) were also comparable, and lower than the corresponding to the untreated sample (not shown here). The slightly higher corrosion resistance provided by the $\mathrm{Cr}^{3+}+\mathrm{Co}^{2+}$-based coating layer was attributed to the synergistic action of factors such as: i) the inhibitive action afforded by the $\mathrm{Co}^{2+}$ [65]; ii) the stability of the $\mathrm{Cr}_{2} \mathrm{O}_{3}$ formed; iii) the effective physic barrier that hinders the oxygen transport to the zinc substrate and, consequently, delays zinc corrosion; and iv) a temporary and limited self-healing effect provided by the small amount of free$\mathrm{Cr}^{6+}$ ions detected in the conversion layer.

\subsection{Impedance measurements}

EIS measurements on $\mathrm{Cr}^{3+}+\mathrm{Co}^{2+}$ or $\mathrm{Cr}^{6+}$-treated electrogalvanized samples as a function of the immersion time in a $0.1 \mathrm{~mol} / \mathrm{L} \mathrm{Na}_{2} \mathrm{SO}_{4}$ solution were carried out to monitor the evolution of the electrochemical behavior of both types of surfaces. EIS data at 1 h, 24 h, 48 h, 72 h, and 96 h of immersion were obtained.

At first glance, a comparative evaluation of the coating corrosion resistance was carried out by observing the values of both the $|\mathrm{Z}|$ at low frequencies and the maximum angle phase. Representative Nyquist (Fig. 5a and b) and Bode (Fig. 6a and b) plots as a function of immersion time are presented for $\mathrm{Cr}^{3+}+\mathrm{Co}^{2+}-$ or $\mathrm{Cr}^{6+}$-treated electrogalvanized steel samples, respectively. At $\mathrm{t}=1 \mathrm{~h}$, the Nyquist plots for (a) $\mathrm{Cr}^{3+}+\mathrm{Co}^{2+}$ or (b) $\mathrm{Cr}^{6+}$ treated samples (Fig. 5) were very different in magnitude and shape. Whereas the spectrum corresponding to the $\mathrm{Cr}^{3+}+\mathrm{Co}^{2+}$-treated sample showed higher impedances and two well defined semi-circles, the spectrum of the $\mathrm{Cr}^{6+}$-treated sample presented a defined semi-circle between the high and medium frequency ranges, which was followed by an inductive loop at the low frequencies. When the conversion coating is present on the zinc surface, the corrosion reactions take place on parts of the surface exposed to the $\mathrm{Na}_{2} \mathrm{SO}_{4}$ solution through pores or defects of the coating. Twentyfour hours after immersion, the second loop (i.e. the low frequency loop) of both samples changed significantly its shape, displaying a

Table 3

Electrochemical parameters obtained from polarization curves.

\begin{tabular}{llllll}
\hline Sample & $\begin{array}{l}\mathrm{E}_{\text {corr }} \\
(\mathrm{V})\end{array}$ & $\begin{array}{l}\mathrm{b}_{\mathrm{a}} \\
(\mathrm{mV} / \mathrm{dec})\end{array}$ & $\begin{array}{l}\mathrm{b}_{\mathrm{c}} \\
(\mathrm{mV} / \mathrm{dec})\end{array}$ & $\begin{array}{l}\mathrm{j}_{\text {corr }} \\
\left(\mathrm{A} / \mathrm{cm}^{2}\right)\end{array}$ & $\begin{array}{l}\mathrm{R}_{\mathrm{p}} \\
\left(\Omega \mathrm{cm}^{2}\right)\end{array}$ \\
\hline Steel/Zn & -1.10 & 11.60 & 15.05 & $4.88 \times 10^{-7}$ & $5.83 \times 10^{3}$ \\
Steel $/ \mathrm{Zn} / \mathrm{Cr}^{6+}$ & -1.05 & 52.70 & 24.20 & $3.00 \times 10^{-7}$ & $4.61 \times 10^{4}$ \\
Steel $/ \mathrm{Zn} / \mathrm{Cr}^{3+}+\mathrm{Co}^{2+}$ & -1.06 & 44.60 & 65.50 & $2.50 \times 10^{-7}$ & $2.40 \times 10^{4}$ \\
\hline
\end{tabular}
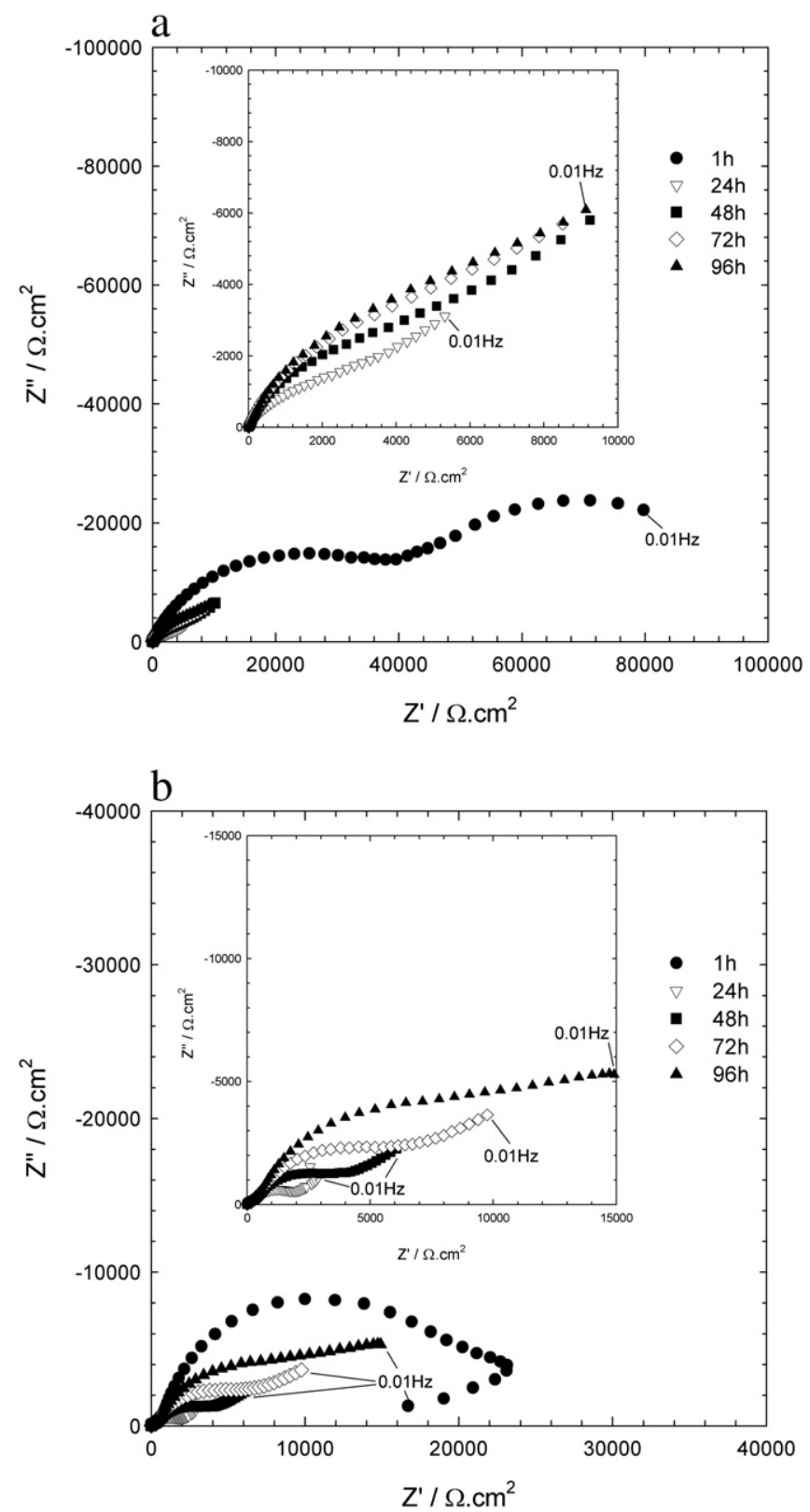

Fig. 5. Effect of immersion time on the Nyquist plots of the (a) $\mathrm{Cr}^{3+}+\mathrm{Co}^{2+}$ - or (b) $\mathrm{Cr}^{6+}$ treated electrogalvanized steel samples in a naturally aerated $0.1 \mathrm{~mol} / \mathrm{L} \mathrm{Na}_{2} \mathrm{SO}_{4}$ solution.

distortion and decrease in their values (see the inserted figures) and suggesting an electrochemically active interface; however, hereafter the impedance increased up to the end of the test $(96 \mathrm{~h})$. It is proposed that the distortions at the low frequency region are caused by a diffusion control reaction or sorption processes taking place on the reactive surface. In the $\mathrm{Cr}^{3+}+\mathrm{Co}^{2+}$-treated samples, initially the corrosion reaction was controlled by the charge transfer resistance (activation control), but at $24 \mathrm{~h}, 48 \mathrm{~h}, 72 \mathrm{~h}$ and $96 \mathrm{~h}$ of immersion, the Warburg or diffusion impedance at low frequencies was indicated. This latter is due to diffusion of the reactant through the conversion and/or the corrosion product layer. In the $\mathrm{Cr}^{6+}$-treated samples, however, the ratedetermining step (rds) of the reaction at low frequencies suggested charge transfer control at $1 \mathrm{~h}, 72 \mathrm{~h}$, and $96 \mathrm{~h}$ of immersion, and by the mass transport process at $24 \mathrm{~h}$ and $48 \mathrm{~h}$ of immersion. Several authors 

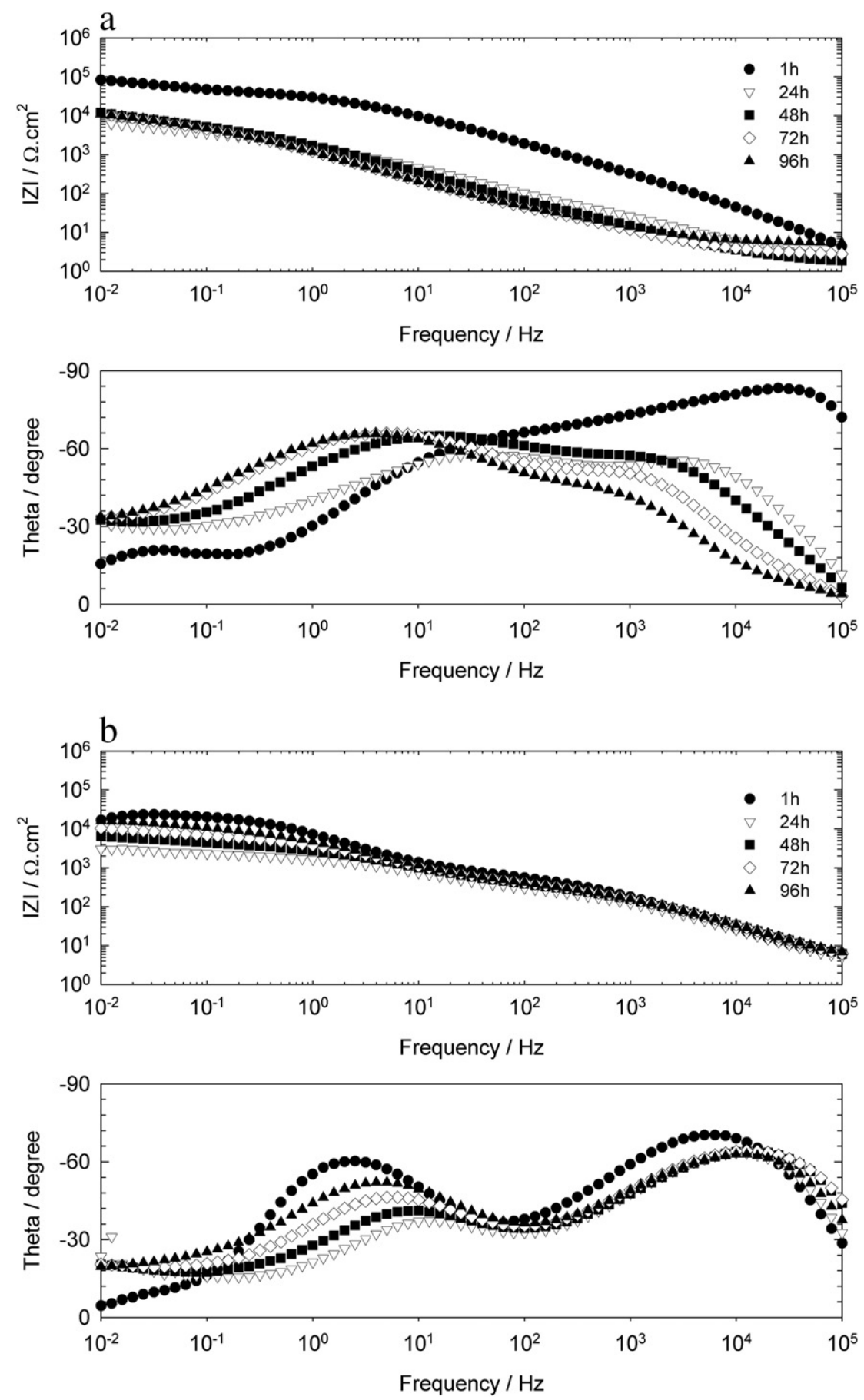

Fig. 6. Effect of immersion time on the Bode plots of the (a) $\mathrm{Cr}^{3+}+\mathrm{Co}^{2+}$ - or (b) $\mathrm{Cr}^{6+}$-treated electrogalvanized steel samples in a naturally aerated $0.1 \mathrm{~mol} / \mathrm{L} \mathrm{Na}_{2} \mathrm{SO}_{4}$ solution.

[66-69] have reported both types of rds for the zinc corrosion in aerated $\mathrm{Na}_{2} \mathrm{SO}_{4}$ solutions.

The experimental data was adjusted to equivalent electric circuits in order to model the results and estimate the values of the resistive and capacitive components.

Fig. 6 shows Bode plots of $\mathrm{Cr}^{3+}+\mathrm{Co}^{2+}$ - or (b) $\mathrm{Cr}^{6+}$-treated samples obtained at different immersion times. At least two time constants are indicated in the Bode plots of the passivated samples. Comparing the performance of the $\mathrm{Cr}^{3+}+\mathrm{Co}^{2+}$ - or $\mathrm{Cr}^{6+}$-treated samples, the slightly higher corrosion resistance shown by the $\mathrm{Cr}^{3+}+\mathrm{Co}^{2+}$-treated samples was in agreement with the small difference observed in the polarization curves. In addition, changes in the phase-angle values along the entire range of frequencies suggest an active mechanism of dissolution- passivation at the conversion layer/zinc interface during the exposure to the electrolyte. This assumption was supported by the appearance of more than one time constant few hours after immersion, which was associated with the presence of microdefects in the conversion layer. Bonora et al. [70] suggested that corrosion products deposited on the micro-cracks of porous coatings could give rise to a new time constant and, therefore, affect the impedance spectra of the coating when it is exposed to corrosive environment.

\subsection{Impedance data deconvolution}

One of the most important difficulties for analyzing the electrochemical impedance data from the impedance spectra deconvolution 
is, in general, to find an electrical equivalent circuit model and/or the parameters to explain the corrosion behavior of each analyzed system.

In this study, the response of the $\mathrm{Cr}^{3+}+\mathrm{Co}^{2+}$ - or $\mathrm{Cr}^{6+}$-treated surfaces to an applied small AC potential perturbation was mostly modeled either by the complete or partial version of the equivalent circuits proposed in Fig. 7. The first time constant $\left(R_{1} C_{1}\right)$ at the highest frequencies represents the resistance to the ionic flux in the pores $\left(R_{1}\right)$ and the dielectric capacitance $\left(C_{1}\right)$ of the conversion layer. As the frequency decreases, and taking into account the permeation of reactants (water, oxygen and ionic species) reaching the electrochemically active areas of the substrate through the coating pores characterized by $R_{1}$, it is reasonable to assume that the corrosion process developing at the zinc surface should be placed in series with $R_{1}$. The $R_{2}$ and $C_{2}$ parameters account for the charge transfer resistance and the electrochemical double layer capacitance of the corrosion process, respectively [71]. As immersion time and zinc dissolution increases, corrosion products could accumulate at the bottom or within the pores. In such circumstances, their contribution to the system impedance would be characterized by the $R_{3}$ and $C_{3}$ parameters [33,57,69-37]. The diffusion component $\mathrm{W}$ obtained at certain exposure times was associated with an oxygen diffusion controlled reaction usually found in zinc corrosion [74,75]; while the inductive component $\mathrm{L}$ obtained at $\mathrm{t}=1 \mathrm{~h}$ in the $\mathrm{Cr}^{6+}$ coating, and shown in Fig. 7a, could be the consequence of the $\mathrm{Cr}^{6+}$ ions desorption in the outer surface of the conversion layer [62].

All time constants exhibited some Cole-Cole type dispersion and its corresponding $n_{i}$ parameter is $0<n_{i} \leq 1$. Furthermore, distortions observed in those resistive-capacitive contributions indicate a deviation from the theoretical models in terms of a time constant distribution. Such deviations might be due to either lateral penetration of the electrolyte at the substrate/coating interface (usually started at the base of intrinsic or artificial coating defects), underlying metallic surface heterogeneities (topological, chemical composition, surface energy), and/or diffusion processes. Considering that all these factors cause non-linearity in the impedance/frequency relationship, they are taken into consideration by replacing one or more capacitive components $\left(C_{i}\right)$ of the equivalent circuit transfer function by a constant phase element $\left(\mathrm{CPE}_{\mathrm{i}}\right)$, whose impedance may be expressed as [76-78]:

$\mathrm{Z}=\frac{(\mathrm{j} \omega)^{-\mathrm{n}}}{\mathrm{Y}_{0}}$

where: $Z(\omega)$ is the impedance of the $\mathrm{CPE}\left(Z=Z^{\prime}+j Z^{\prime \prime}\right)(\Omega)$, j is the imaginary number $\left(j^{2}=-1\right), \omega$ is the cathodic reactions involved in the zinc (rad) is the, $n$ is the CPE power: $(n=\alpha /(\pi / 2)), \alpha$ is the constant phase angle of the CPE (rad), and $\mathrm{Y}_{0}$ is part of the CPE independent of the frequency $\left(\Omega^{-1}\right)$.

An accurate physical description of the occurred processes is not an easy task. In such cases, a standard deviation $\left(\chi^{2}\right) \leq 5.10^{-4}$ was used as a criterion of acceptance, considering that the smaller this value, the closer the fit to the experimental data [55]. In the present work, the fitting process was carried out using constant phase elements $\left(\mathrm{CPE}_{\mathrm{i}}\right)$ instead of the dielectric capacitance $C_{i}$, although, $C$ was used in the following plots in order to facilitate the result visualization and interpretation.

The values of the $R_{1}, C_{1}, R_{2}, C_{2}, R_{3}, C_{3}$ and $W$ parameters estimated from the impedance spectra fitting analysis as a function of immersion time are reported in Fig. 8a-h.

\subsection{Time dependence of the impedance resistive and capacitive components}

Fig. 8a-h shows the evolution of the $\mathrm{E}_{\text {corr }}$ and the development of each component of the equivalent circuits as a function of immersion time in a naturally aerated $0.1 \mathrm{~mol} / \mathrm{L} \mathrm{Na}_{2} \mathrm{SO}_{4}$ solution. As previously mentioned, the zinc corrosion reaction seemingly initiated just after immersion. Consequently, $\mathrm{E}_{\text {corr }}$ values remained nearly invariable along immersion.

The resistance to the ionic flux $\left(\mathrm{R}_{1}\right)$ of the $\mathrm{Cr}^{3+}+\mathrm{Co}^{2+}$ samples decreased after $24 \mathrm{~h}$ of immersion, and then slowly increased up to $96 \mathrm{~h}$. In the $\mathrm{Cr}^{6+}$-coated samples the $\mathrm{R}_{1}$ values were about one order of magnitude higher than those corresponding to $\mathrm{Cr}^{3+}+\mathrm{Co}^{2+}$ samples and were also much more stable, Fig. 8b. The ionic resistance varied in the range of $10^{2}-10^{3} \Omega \mathrm{cm}^{2}$ for the $\mathrm{Cr}^{3+}+\mathrm{Co}^{2+}$ samples, while it was in the range from 4 to $8 \times 10^{3} \Omega \mathrm{cm}^{2}$ for the $\mathrm{Cr}^{6+}$-treated samples, i.e., values fairly smaller than those measured for the charge transfer resistance $\left(R_{2}\right)$ of both conversion coatings and the resistance of the zinc corrosion products $\left(\mathrm{R}_{3}\right)$, Figs. 8d and $\mathrm{f}$, respectively. As a result, this indicates that the contribution of $R_{1}$ to the corrosion resistance was very poor. Initially, the coating capacitance $\left(\mathrm{C}_{1}\right)$ of the $\mathrm{Cr}^{3+}+\mathrm{Co}^{2+}$ samples increased to approximately two orders of magnitude with the immersion time, but then stabilized at approximately $8 \times 10^{-4} \mathrm{~F} \mathrm{~cm}^{-2}$ up to the $96 \mathrm{~h}$. Similarly to the ionic resistance $\left(\mathrm{R}_{1}\right)$ for the $\mathrm{Cr}^{6+}$-treated samples and the coupled coating capacitance $\left(C_{1}\right)$ presented small changes. According to previous reports [79,80], the increase of the $C_{1}$ values for the $\mathrm{Cr}^{3+}+\mathrm{Co}^{2+}$ samples can be due to either the increased surface area caused by the degradation of the coating and/or increased dielectric constant due to water uptake.

a

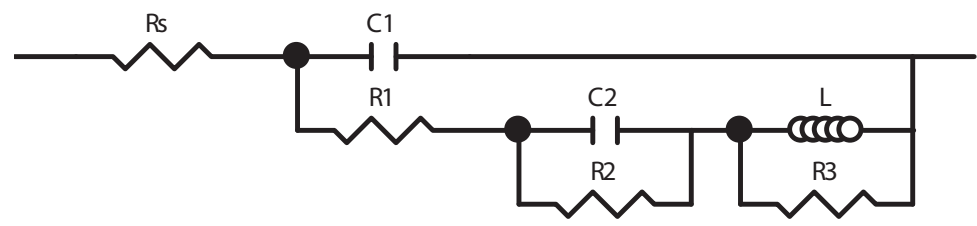

$\mathrm{b}$

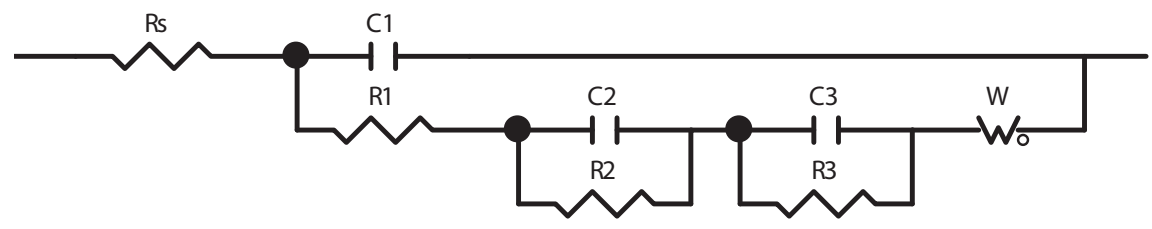

Fig. 7. Equivalent circuits used to model $\mathrm{Cr}^{3+}+\mathrm{Co}^{2+}$ - or $\mathrm{Cr}^{6+}$-treated samples immersed in a naturally aerated $0.1 \mathrm{~mol} / \mathrm{L} \mathrm{Na}_{2} \mathrm{SO}_{4}$ solution for $96 \mathrm{~h}$. 

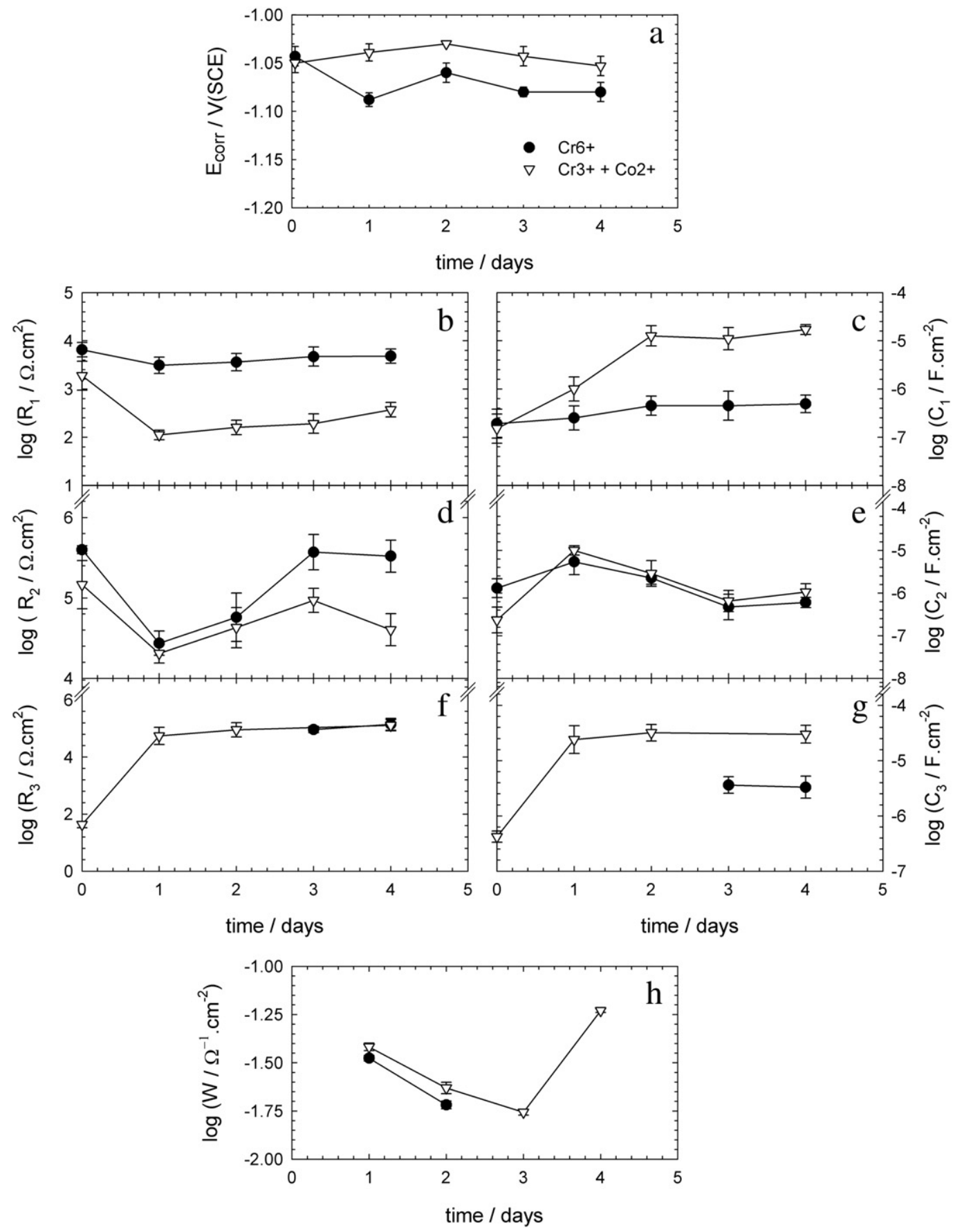

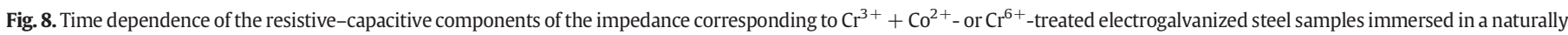
aerated $0.1 \mathrm{~mol} / \mathrm{L} \mathrm{Na}_{2} \mathrm{SO}_{4}$ solution for $96 \mathrm{~h}$.

Initially the charge transfer resistance $\left(\mathrm{R}_{2}\right)$ of the $\mathrm{Cr}^{3+}+\mathrm{Co}^{2+}$ - or $\mathrm{Cr}^{6+}$-coated samples decreased with immersion time, Fig. 8d. Then, from $24 \mathrm{~h}$ to $72 \mathrm{~h}$ of immersion, $\mathrm{R}_{2}$ values increased, likely due to the migration of $\mathrm{Cr}^{6+}$ species towards the coating defects followed by a temporary repassivation. However, this "self-healing" effect is limited because the reduction of $\mathrm{Cr}^{6+}$ to $\mathrm{Cr}^{3+}$ is irreversible and the supply of mobile $\mathrm{Cr}^{6+}$ species decreases with time. The higher $\mathrm{R}_{2}$ values associated to the $\mathrm{Cr}^{6+}$-treated samples might be due to the larger concentration of $\mathrm{Cr}^{6+}$ ions in these samples, as shown by XPS analysis. The final decrease was associated to the propagation of microdefects as the exposure time elapsed. At the beginning of the test, and in agreement with the $R_{2}$ decay, the double-layer capacitance $\left(C_{2}\right)$ of both samples increased abruptly, Fig. 8e. This parameter is proportional to the active area in the electrochemical reactions, i.e. the surface area of the microdefects in contact with the electrolyte. The initial increment of the $C_{2}$ values may be indicative of a fast increase in the electrochemically active surface within the microdefects. The increase in $R_{2}$ was accompanied by the decrease of the coupled $C_{2}$ element, likely due to the reduction of the reactive area caused by the mobile $\mathrm{Cr}^{6+}$ ions up to the exhaustion of those ions when $C_{2}$ increases again.

For the $\mathrm{Cr}^{3+}+\mathrm{Co}^{2+}$-treated samples the contribution of the corrosion product resistance $\left(R_{3}\right)$ to the total impedance increased significantly from $1 \mathrm{~h}$ to $24 \mathrm{~h}$ of immersion but then remained fairly stable, Fig. $8 f$. However, for the $\mathrm{Cr}^{6+}$-passivated samples, $\mathrm{R}_{3}$ appears only after an induction period of $72 \mathrm{~h}$. At $1 \mathrm{~h}$ the $\mathrm{R}_{3}$ was associated to an adsorption process, while at $24 \mathrm{~h}$ and $48 \mathrm{~h}$ it was masked by a diffusion process. 
Campestrini et al. [81] reported that corrosion products deposited within the micro-defects of chromium conversion layers could affect the mass transport through those layers. Accordingly, it was assumed that the increase in $\mathrm{R}_{3}$ was due to the increased amount of corrosion products, which acted as a diffusion barrier for ions, such as $\mathrm{SO}_{4}^{2-}$. As longer immersion periods, the area affected by corrosion increased and defect propagation occurred, resulting in the loosening of the corrosion products and decreased barrier properties. The $C_{3}$ values, associat-

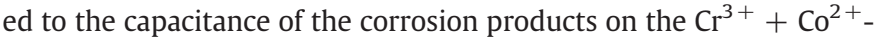
treated samples, initially increased but then it reminded significantly unchanged for longer periods of immersion, Fig. 8g.

After $24 \mathrm{~h}$ of induction period, the rds of the corrosion reaction changed from activation to mass transport control. The impedance of this mass transport controlled reaction (W) is shown in Fig. 8h, as a function of the immersion time. For the $\mathrm{Cr}^{6+}$-treated samples, the $\mathrm{W}$ values increased rapidly up to $48 \mathrm{~h}$ and disappeared, whereas for the $\mathrm{Cr}^{3+}+\mathrm{Co}^{2+}$-passivated samples it continued to grow up to $72 \mathrm{~h}$ of immersion and then decreased. The $\mathrm{W}$ impedance that increases with time is related to the hindered transport of species such as $\mathrm{SO}_{4}^{2-}$ ions and oxygen through the micro-defects in both conversion coatings due to the blocking action of zinc corrosion products deposited at the bottom and/or within the coatings microdefects. The decrease in the diffusion or Warburg type impedance, on the other hand, is related to either micro-defect enlargement and/or loosening of corrosion products favoring the diffusion of the reactant species.

\section{Conclusions}

In the present work the corrosion resistance of industrially electrogalvanized steel covered with $\mathrm{Cr}^{3+}+\mathrm{Co}^{2+}$ or $\mathrm{Cr}^{6+}$-based passivation treatment was investigated in a naturally aerated $\mathrm{Na}_{2} \mathrm{SO}_{4}$ solution for $96 \mathrm{~h}$. From the experimental results the following main conclusions were drawn.

Both pretreatments showed good protection against corrosion and the observed $\mathrm{j}_{\text {corr }}$ values were approximately $40-50 \%$ inferior to those observed for non-treated samples.

The electrochemical results (polarization curves and EIS) indicated higher corrosion resistance associated to the $\mathrm{Cr}^{3+}+\mathrm{Co}^{2+}$-treated samples comparatively to the $\mathrm{Cr}^{6+}$-treated ones. This was ascribed to: i) the stability of the $\mathrm{Cr}_{2} \mathrm{O}_{3}$; ii) the effective physic barrier that hinders the oxygen transport to the zinc substrate; and iii) a temporary and limited self-healing effect provided by the small amount of free- $\mathrm{Cr}^{6+}$ ions in the conversion layer. The most commonly observed failures on the $\mathrm{Cr}^{6+}$ treated samples were attributed to microstructural features of the substrate that were not adequately healed by the $\mathrm{Cr}^{6+}$ passivation treatment.

\section{Acknowledgments}

The authors wish to acknowledge the CAPES/MINCyT (Process 158/09 of Brazil and BR/08/04 of Argentina), the Comisión de Investigaciones Cientificas de la Provincia de Buenos Aires (CICPBA), the Consejo Nacional de Investigaciones Científicas y Técnicas (CONICET) and the Universidad Nacional de La Plata of Argentina for the financial support to this research.

Acknowledgement is also due to the Brazilian Nanotechnology National Laboratory, CNPEM/MCTI-LMN - Laboratory of Nanostructured Materials (LNNano) for the XPS analysis.

\section{References}

[1] N. Zaki, Met. Finish. 86 (1988) 75-76.

[2] Directive Number 2003/53/EC of the European Parliament and Council, 18 June 2003.

[3] Directive Number 2011/65/EU (RoHS2), of the European Parliament and Council, Restriction of Hazardous Substances, July, 2011.

[4] T.K. Route, N. Bandyopadhyay, Methods Mater. 54 (1) (2007) 16-20.

[5] D.E. Walker, G.D. Wilcox, Trans. 86 (5) (2008) 251-259.
[6] D. Rodríguez, D. Chidambaram, ECS Trans. 45 (19) (2013) 91-103.

[7] C.G. da Silva, A.N. Correia, P. de Lima-Neto, I.C.P. Margarit, O.R. Mattos, Corros. Sci. 47 (3) (2005) 709-722.

[8] R.E. Van de Leest, G. Krijl, Thin Solid Films 72 (2) (1980) 237-246.

[9] R. Bauer, M. Malik, Aluminum treatment composition, US Patent EP 2265740 A1 (2010).

[10] A.S. Hamdy, H.M. Hussien, Int. J. Electrochem. Sci. 8 (2013) 11386-11402.

[11] A.E. Hughes, J.D. Gorman, T.G. Harvey, A. Galassi, G. McAdam, Corrosion 62 (9) (2006) 773-780.

[12] A.S. Hamdy, H.M. Hussien, Int. J. Electrochem. Sci. 9 (2014) 2682-2695

[13] E. Almeida, T.C. Diamantino, M.O. Figueiredo, C. Sá, Surf. Coat. Technol. 106 (1) (1998) 8-17.

[14] Y. Ma, N. Li, D. Li, M. Zhang, X. Huang, Appl. Surf. Sci. 261 (2012) 59-67.

[15] K.H. Yang, M.D. Ger, W.H. Hwu, Y. Sung, Y.C. Liu, Mater. Chem. Phys. 101 (2-3) (2007) 480-485.

[16] E.J. Siebert, B.H. Goodreau, Zirconium-based coating composition and processes, US Patent WO 2012178003 A2 (2012).

[17] S.H. Wang, C.S. Liu, L. Wang, Adv. Mater. Res. 291-294 (2011) 47-52.

[18] Y. Guan, J. Liu, C. Yan, Int. J. Electrochem. Sci. 6 (2011) 4853-4867.

[19] A. Bodaghi, J. Hosseine, Int. J. Electrochem. Sci. 7 (2012) 2584-2595.

[20] G.D. Wilcox, J.A. Wharton, Trans. (1997) B140-B146.

[21] R.G. Duarte, A.C. Bastos, A.S. Castela, M.G.S. Ferreira, Prog. Org. Coat. 52 (2005) 320-327.

[22] C.R. Tomachuk, A.R. Di Sarli, J. Eng. Technol. 1 (2012) 78-96.

[23] C.R. Tomachuk, C.I. Elsner, A.R. Di Sarli, J. Mater. Sci. Eng. A 2 (2012) 693-711.

[24] W. Trabelsi, E. Triki, L. Dhouibi, M.G.S. Ferreira, M.L. Zheludkevick, M.F. Montemor, Surf. Coat. Technol. 200 (2006) 4240-4250.

[25] G. Kong, J. Lu, H. Wu, J. Rare Earths 27 (1) (2009) 164-168.

[26] W. Xiao, R. Man, Ch. Miao, T. Peng, J. Rare Earths 28 (1) (2010) 117-122.

[27] M. Fedel, M.-E. Druart, M. Olivier, M. Poelman, F. Deflorian, S. Rossi, Prog. Org. Coat. 69 (2010) 118-125.

[28] S.H. Zaferani, M. Peikaria, D. Zaarei, I. Danaee, J. Adhes. Sci. Technol. (2013), http:// dx.doi.org/10.1080/01694243.2013.779068.

[29] V.R. Capelossi, I.V. Aoki, Prog. Org. Coat. 76 (2013) 812-820.

[30] S.H. Zaferani, M. Peikari, D. Zaarei, I. Danaee, J.M. Fakhraei, M. Mohammadi, Corrosion 69 (4) (2013) 372-387.

[31] P.R. Seré, C. Deyá, W.A. Egli, C.I. Elsner, A.R. Di Sarli, J. Mater. Eng. 23 (1) (2014) $342-348$.

[32] K. Aramaki, Corros. Sci. 43 (2001) 2201-2215

[33] C.R. Tomachuk, C.I. Elsner, A.R. Di Sarli, Port. Electrochim. Acta 30 (2012) 145-162.

[34] C.R. Tomachuk, C.I. Elsner, A.R. Di Sarli, Mater. Res. 17 (1) (2014) 61-68.

[35] J.D. Culcasi, C.I. Elsner, A.R. Di Sarli, L. Palomino, C.R. Tomachuk, I. Costa, Chem. Technol. 9 (3) (2014) 85-94.

[36] C.R. Tomachuk, A.R. Di Sarli, C.I. Elsner, Mater. Sci. Applic. (2010) 202-209.

[37] C.R. Tomachuk, C.I. Elsner, A.R. Di Sarli, O.B. Ferraz, J. Coat. Technol. Res. 7 (4) (2010) 493-502.

[38] M. Olivier, A. Lanzutti, C. Motte, L. Fedrizzi, Corros. Sci. 52 (2010) 1428-1439.

[39] T. Prosek, D. Thierry, C. Taxen, J. Maixner, Corros. Sci. 49 (2007) 2676-2693.

[40] I.M. Zin, S.B. Lyon, V.I. Pokhmurskii, Corros. Sci. 45 (2003) 777-788.

[41] X. Jiang, Y.G. Zheng, D.R. Qu, W. Ke, Effect of calcium ions on pitting corrosion and inhibition performance in $\mathrm{CO}_{2}$ corrosion of N80 steel, Corros. Sci., 48 (52006) 3091-3108.

[42] A. Aït Aghzzaf, B. Rhouta, E. Rocca, A. Khalil, J. Steinmetz, Corros. Sci. 80 (2014) 46-52.

[43] J. Peultier, E. Rocca, J. Steinmetz, Corros. Sci. 45 (2003) 1703-1716.

[44] A. Frignani, V. Grassi, F. Zucchi, F. Zanotto, Mater. Corros. 62 (11) (2011) 995-1002.

[45] C. Georges, E. Rocca, P. Steinmetz, Electrochim. Acta 52 (2008) 4839-4845.

[46] P. Preikschat, R. Jansen, Chromatierungen und Passivierungen auf Zink und Zinklegierungen, SurTec International GmbH, http://www.surtec.ch/index.php? $\mathrm{id}=38$.

[47] ASTM B1172011. (12 pp.).

[48] DIN Testing in a saturated atmosphere in the presence of sulphur dioxide, DIN 50018:2013-05.

[49] Atmospheres and their technical application condensation water test atmospheres, DIN 50017:1982-10. 5p.

[50] J.R. MacDonald, Impedance Spectroscopy Emphasizing Solid State Materials, Ed. J. Wiley \& Sons, New York, 1987.

[51] F. Mansfeld, Electrochim. Acta 38 (1993) 1891-1897.

[52] C.I. Elsner, D.B. del Amo, L.S. Hernández, A.R. Di Sarli, J. Chem. Eng. 92 (4) (2014) 623-632.

[53] P.R. Seré, C. Deyá, C.I. Elsner, A.R. DiSarli, Int. J. Adhes. Adhes. 50 (2014) 1-6.

[54] ASTM2009. B568-B598.

[55] A. Boukamp, University of Twente, The Netherlands, 1989.

[56] C.R. Tomachuk, C.I. Elsner, A.R. Di Sarli, O.B. Ferraz, Mater. Chem. Phys. 119 (2010) 19-29.

[57] M. Mouanga, L. Ricq, P. Berçot, Surf. Coat. Technol. 202 (9) (2008) 1645-1651.

[58] J. Ribeiro Garcia, D.C. Baptista do Lago, L. Ferreira de Senna, Mater. Res. (2014), http://dx.doi.org/10.1590/S1516-14392014005000096.

[59] N.M. Martyah, J.E. McCaskie, L. Harrison, Met. Finish. 94 (2) (1996) 65-67.

[60] K.W. Cho, V.S. Rao, H. Kwon, Electrochim. Acta 52 (13) (2007) 4449-4456.

[61] M.P. Gigandet, J. Faucheu, M. Tachez, Surf. Coat. Technol. 89 (3) (1997) 285-291.

[62] X. Zhang, C. van den Bos, W.G. Sloof, A. Hovestad, H. Terryn, J.H.W. de Wit, Surf. Coat. Technol. 199 (1) (2005) 92-104.

[63] C.V. D'Alkaine, M.N. Boucherit, J. Electrochem. Soc. 144 (1997) 3331-3336.

[64] R.M. Krishnan, S.R. Natarajan, V.S. Muralidharan, G. Singh, Key Eng. Mater. 20-28 (1988) 1325-1332. 
[65] H. Leidheiser, I. Suzuky Jr., J. Electrochem. Soc. 128 (1981) 242-249.

[66] C. Deslouis, M. Duprat, C. Tulet-Tournillon, J. Electroanal. Chem. 181 (1984) 119-136.

[67] C. Deslouis, M. Duprat, C. Tulet-Tournillon, Corros. Sci. 29 (1989) 13-30.

[68] C. Cachet, C. de Pauli, R. Wiart, Corros. Sci. 25 (1985) 493-502.

[69] C.M. Rangel, L.F. Cruz, Corros. Sci. 33 (9) (1992) 1479-1493.

[70] P.L. Bonora, F. Deflorian, L. Fedrizzi, Electrochim. Acta 41 (7-8) (1996) 1073-1082.

[71] L. Fedrizzi, L. Ciaghi, B.L. Bonora, R. Fratessi, G. Roventi, J. Appl. Electrochem. 22 (3) (1992) 247-254.

[72] M. Dattilo, J. Electrochem. Soc. 132 (11) (1985) 2557-2561.

[73] F. Deflorian, S. Rossi, L. Fedrizzi, P.L. Bonora, Prog. Org. Coat. 52 (4) (2005) 271-279.

[74] C. Cachet, R. Wiart, J. Electroanal. Chem. 111 (1980) 235-246 (ibid. 129 (1981) 103114).
[75] A. Amirudin, D. Thierry, Prog. Org. Coat. 26 (1) (1995) 1-28.

[76] C.M. Abreu, M. Izquierdo, M. Keddam, X.R. Nóvoa, H. Takenouti, Electrochim. Acta 41 (15) (1996) 2405-2415.

77] B. del Amo, L. Véleva, A.R. Di Sarli, C.I. Elsner, Prog. Org. Coat. 50 (3) (2004) 179-192

[78] E.P.M. van Westing, G.M. Ferrari, F.M. Geenen, J.H.W. de Wit, Prog. Org. Coat. 23 (1) (1993) 89-103.

[79] T. Belleze, G. Roventi, R. Fratesi, Surf. Coat. Technol. 155 (2002) 221-230.

[80] P. Campestrini, E.P.M. van Westing, A. Hovestad, J.H.W. de Wit, Electrochim. Acta 47 (2002) 1097-1113.

[81] P. Campestrini, E.P.M. van Westing, J.H.W. de Wit, Electrochim. Acta 46 (2001) 2631-2647. 